"When Loder was studying at the Hotel Dieu at Rouen, a man came to the hospital. on account of some trifling-complaint. The celebrated $M$. David then the principal surgeon of that establishment, perceived that the paiient had also a dislocation of the left arm. 'The displacement had alrearlv existed several months, and the lamb had acquired some degree of mobility. M. David recommended making a fresh trial to reduce the bone, and the patient's consent being obtained, the attempt was made with immense force, and the arm restored to its proper place again; but the event was most disastrous; for the whole limb was attacked with such riolent pain and inflammation, that notwi,hstanding every means which surgery could suggest was immediately put in practice, mortification ensued, and the patient lost his life."

The foregoing obserrations are calculated to exhibit the trentment of luxations of the os humeri as sanctioned and pursue! by the best surgi. cal authorities, and to show that the practice thus established, if not uniformly successful, has, with the exception of two or three cases, been t,nattended with danger. A question, however, may possibly arise-whether surgeons should be imfuenced by the event of the case I have detailed, and by those I have quoted, and deterred altngether from atiempting reituction in dislocations of long standing. or whether the established practice should still be continued, unatiected by fortuitous circumstances or contingencies neither to be forseen no: controlled? To the latter proposition I have no hesitation to give unqualified assent, and to declare, that should a case similar in exterieal appearance to that of James Scofield again occur, I shall feel jusfified in adopting a similar course.

We will give a few remarks on the abore case in our next number.

* First lines of the Practice of Surgery, by S. Ccoper. Vol. 11. 1. $\$ 66$.

\section{REMARKS ON SUICIDE,}

BY PRONESSOR GROHMANN, OF.HANRURGH.

A calculation has been made in England, founded upon observations "made during ten years, from which it appears that suicides are more frequent in England in the month of July than in any other part of the year; that they decrease in the following prograssion; Iune, March, January, February, November, December, April. August, September, May, and that the month of October is that in which the fewest suicides are committed. Pursuing the same course of observation, Professor Gromuann, after having discussed the causes of suicide in 'THeland's Medicul Journal, gives the following table of suicides, which took place at Hamburgh from the year 1816, to the yoar 1822, inclusive:

Table of the Sxicides observed at Hamburgh jrom the year 1816 to 1822. -

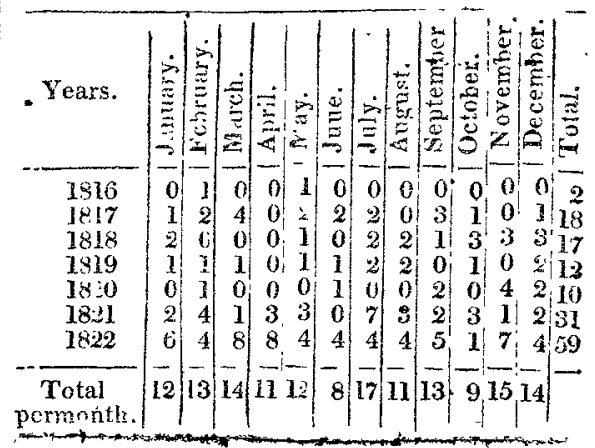


It appears from this table that | ber thirteen; while in Decemthe saicidès at Hamburgh, as in England, were more frequent in July than in the other months of the year, since in seven years there were seventeen suicides in that month, a larger number than that which occurred in any other month, The month of October also appears to be one in which a small number of suicides took place, since in the same space of seven years, only nine persons destroyed themselves ; in the month of June, however, there were only eight suicides. M. Grohmann thinks the frequency of suicides in the month of July is to be attributed to the influence of the season, the excessive heat, and the use of spirituous liquors during the summer. We must observe, however, says the Revue Medigale, that M. GrohmanN's opinion does not coincide with the results of his own observations, since in the month of June there appear to have been eight suicides, in August eleven, and in Septem-

ber, January; February, and March there were twelve, thirteen, and fourteen suicides; so that in the four hot months there were only 49 suicides, while in the four cold ones there were fifty-three. Besides, more suicides have not been observed to take place in hot, than in cold countries. In examining the table attentively, we cannot observe without astonishment and concern the melancholy difference between the number of suicides which took place at Hamburgh from 1816 to 1820 , and from 1821 to 1823 , since in 1816 Hamburgh had only to deplore the loss of two individuals from this cause, and in 1819 and 1820 ten or twelve ; while in 1821 , the list increased to three times that amount, and in 1822 to four times that amount. M. GroHMANN does not suggest any. cause for this melancholy disproportion.-Revue Medicale, March.

Published by Kniant and Lacex, Paternoster row; London, at an early hour every Saturday morning, and sold by their Agents in every Town in - the United Kingdom.

Printed at Tre Iancer Office, New Church Court, Opposite Somerset House, Strand, London; where all publications for Review, Literary Intelligence,

Communications, and Advertisements are to be forwarded (pest-paid) to the Editor. 